\title{
Isolation of Secondary Metabolites from Leucas aspera and Investigation of Biological Activity
}

\author{
Md. Selim Aktar Reza, Md. Hasanur Rahman and Tofail Ahmad Chowdhury* \\ Department of Chemistry, University of Dhaka, Dhaka-1000, Bangladesh
}

( Received : 30 December 2019; Accepted : 7 January 2020 )

\begin{abstract}
Leucas aspera plant was subjected to isolation of secondary metabolites and screening of their biological activities. Four compounds, stigmasterol, lupeol, $\beta$-sitosterol and menthol, were isolated from methanol extract. Sixteen different microorganisms were used for investigating antimicrobial activity of the different extracts of $L$. aspera where noteworthy zone of inhibition was observed against Gram positive B. subtilis and $S$. aureus, B. megaterium and Gram negative $S$. paratyphi, $S$. typhi, $V$. mimicus, $S$. dysenteriae and $V$. cholera. In brine shrimp lethality bioassay, the highest lethality was showed by crude methanol extract having $\mathrm{LC}_{50}$ values of $4.07 \mu \mathrm{g} / \mathrm{mL}$. The total antioxidant capacity of crude methanol fraction was found to be $59.40 \mathrm{mg} / \mathrm{g}$ of plant extract which was maximum comparing with other fractions. No significant cytotoxicity was observed on both HeLa and Vero cell at $1 \mathrm{mg} / \mathrm{mL}$ sample inhibition.
\end{abstract}

Keywords: Secondary metabolites, Antimicrobial, Lethality bioassay, Antioxidant, Cytotoxicity.

\section{Introduction}

L. aspera (Family: Lamiaceae) commonly known as 'Dondokalash' is one such medicinal plant which is being used traditionally for antipyretic, analgesic, antiinflammatory, anti-rheumatic and antibacterial treatment and paste of the plant is subjected to inflamed area ${ }^{1}$. Leaves of $L$. aspera is traditionally used for the remedy of colds, coughs, chronic skin eruption, painful swelling, wound healing and even used as insecticide ${ }^{2}$. Alcoholic extract $(90 \%)$ of $L$. aspera showed antiulcer effect which significantly reduced acid secretion ${ }^{3}$ and ethanol extract capable of exhibiting antihyperglycemic activity ${ }^{4}$. Phytochemical examination is revealed the presence of terpenoids in whole plant ${ }^{5}$. Nicotine $^{6}$, sterols ${ }^{7}$ and other alkaloids ${ }^{8}$ have been isolated from the aerial part of the plant. Novel phenolic compounds such as [4- (24-hydroxy-1-oxo-5-n-propyltetracosanyl)phenol] ${ }^{9}$, aliphatic ketols, (28-hydroxypentatriacontan-7-one and 7-hydroxydotriacontan-3-one) ${ }^{\mathbf{1 0}}$ have been isolated from the roots of $L$. aspera. The volatiles, u- farnesene, $\mathrm{x}$-thujene and menthol are the major constituents of the leaves and amyl propionate and isoamyl propionate are dominant ${ }^{11}$ in flower of L. aspera.

Considering the potential bioactivity, the plant materials have been chosen for further studies to find out their unexplored efficacy and isolation of a new compound.

\section{Experimental}

\section{Collection of sample}

The whole plant of L. aspera was collected from Panchagarh, Bangladesh and washed to remove mud and dust particles. Taxonomic identification was confirmed by the renowned plant taxonomist Professor Dr. Mohammad Zashim Uddin, Department of Botany, University of Dhaka. The collected fresh plant crushed into powder and stored in an airtight container.

\section{Phytochemical screening}

Phytochemical screening was carried out using standard procedure $^{12}$ for identifying the chemical constituents. The presence of saponins, tannins, steroids, flavonoids, terpenoids and cardiac glycosides were observed in $L$. aspera plant.

\section{Extraction}

The dried powder $(800 \mathrm{~g})$ of $L$. aspera plant was taken in a clean, round bottomed flask and extracted with n-hexane followed by methanol at room temperature and atmospheric pressure. The extracts were evaporated to dryness at $40^{\circ} \mathrm{C}$ using a rotary evaporator (Buchi, Switzerland) under reduced pressure. The amount of methanol extract was found to be $4.9 \mathrm{~g}$.

Isolation and characterization of compounds from methanol extract

The methanol extract was subjected to column chromatography over column grade silica gel using hexane as eluting solvent with increasing percentage of dichloromethane, ethyl acetate and methanol, respectively, from where thirty six fractions were collected. Studying on TLC plate similar fractions were combined together and renamed as $F_{1}$ to $F_{13}$. Among the fractions, $\mathrm{F}_{6}$ showed single spot on TLC plate and it was remarked as LA-2. Fraction $\mathrm{F}_{9}$ was appeared to contain two spots and fractionated by preparative TLC. The preparative TLC was developed using DCM:EA (9:1) mixed solvent and a pure compound was isolated, which was LA-1. The fraction $F_{10}$ appeared to contain four spots. This fraction was subjected to sub column for further fractionation. Each of the fractions from sub column was monitored by TLC and similar fractions were combined together and marked as $\mathrm{P}_{1}$ to $\mathrm{P}_{7}$ where fraction $\mathrm{P}_{6}$ was found to be a pure compound. This isolated pure compound was marked as LA-3. The compound LA-4 was isolated by using steam distillation technique. 


\section{Extraction of plant for biological activity screening}

Freshly prepared whole plant powder was extracted with hexane, chloroform, dichloromethane, ethyl acetate and methanol at room temperature respectively. All the extracts were evaporated to dryness and used for antimicrobial activity screening, brine shrimp lethality bio assay, cytotoxicity assay on cancer cell lines and determination of total antioxidant capacity using their individual standard procedure $^{13,14}$.

\section{Results and Discussion}

\section{Characterization of compound LA-1}

Compound LA-1 was white crystalline solid having $\mathrm{R}_{\mathrm{f}}$ value 0.78 (in $80 \%$ DCM:20\% Ethyl acetate) and soluble in chloroform and dichloromethane. The melting point of LA1 was found to be $157-160^{\circ} \mathrm{C}$. ${ }^{1} \mathrm{H}$ NMR spectrum $(400$ $\mathrm{MHz}, \mathrm{CDCl}_{3}$ ) of compound LA-1 showed peaks at $\delta 5.38$, $5.13,5.00,3.51,1.01,0.89,0.83$ and $0.67 \mathrm{ppm}$. The presence of a multiplet at $\delta 3.51 \mathrm{ppm}$ in ${ }^{1} \mathrm{H}$ NMR indicated the presence of oxymethine proton. The downfield signals at $\delta 5.0$ and $5.13 \mathrm{ppm}$ revealed the presence of olefinic protons. The other signals of the spectrum between $\delta 1.05$ $2.30 \mathrm{ppm}$ were due to the presence of different methylene ($\mathrm{CH}_{2-}^{-}$) and methine (>CH-) protons. ${ }^{13} \mathrm{C} \mathrm{NMR}$ spectrum $\left(100 \mathrm{MHz}, \mathrm{CDCl}_{3}\right.$ ) of compound LA-1 showed peaks at $\delta$ $37.27,31.69,31.69,42.34,140.78,121.72,31.92,31.92$, $50.16,36.52,19,39.79,42.33,56.8,23.03,29.18,56.08$, 11.98, 19.04, 39.8, 21.1, 138, 129, 51.24, 31.92, 18.78 , 24.31, 11.86 and $21.21 \mathrm{ppm}$. The ${ }^{13} \mathrm{C}$ NMR spectrum (100 $\mathrm{MHz}$ in $\mathrm{CDCl}_{3}$ ) of isolated compound LA-1 showed the presence of twenty nine (29) carbon signals. The signals at $\delta 140.78,138,129.0$ and 121.72 ppm were observed due to the presence of olefinic carbons. From the physical characteristics and spectral analysis $\left({ }^{1} \mathrm{H}\right.$ NMR and ${ }^{13} \mathrm{C}$ NMR) data of the compound LA-1 and comparing the reported value ${ }^{15}$ of ${ }^{1} \mathrm{H}$ NMR and ${ }^{13} \mathrm{C}$ NMR spectral data of stigmasterol, the structure of the compound was established as stigmasterol.

\section{Characterization of compound LA-2}

Physical appearance of compound LA-2 was white crystalline having $\mathrm{R}_{\mathrm{f}}$ value 0.56 (in $100 \%$ DCM) and soluble in chloroform, dichloromethane. The melting point of LA-2 was found to be $120-122^{\circ} \mathrm{C}$. FT-IR spectrum of the compound LA-2 showed absorption band at 3056, 2929, 1593, 1450, 1435, 1265 and $898 \mathrm{~cm}^{-1}$. IR spectrum showed characteristic absorption frequencies at 3392 and $1188 \mathrm{~cm}^{-1}$ typical of the $\mathrm{O}-\mathrm{H}$ and $\mathrm{C}-\mathrm{O}$ bond vibrations, respectively; the absorption at $889 \mathrm{~cm}^{-1}$ was indicative of an unsaturated out of plane $\mathrm{C}-\mathrm{H}$ vibration; the absorption at $1748 \mathrm{~cm}^{-1}$ was indicative of the $\mathrm{C}=\mathrm{C}$ vibrations. ${ }^{1} \mathrm{H}$ NMR spectrum (400 $\mathrm{MHz}, \mathrm{CDCl}_{3}$ ) of compound LA-2 revealed peaks at $\delta 4.71$, 4.56, 3.2, 2.37, 1.91, 1.67 and 0.69-1.54 ppm. In ${ }^{1} \mathrm{H}$ NMR spectrum, a multiplet at $\delta 3.2 \mathrm{ppm}$ while a pair of broad singlets at $\delta 4.56$ and $\delta 4.71 \mathrm{ppm}(1 \mathrm{H}$, each) was indicative of olefinic protons. The signals between $\delta 0.69-1.54 \mathrm{ppm}$ were due to several methylene and methane protons and a multiplet signal of one proton at $\delta 2.37$ ascribable to $19 \beta-$ $\mathrm{H}$ is characteristic of Lupeol. ${ }^{13} \mathrm{C}$ NMR spectrum (100 $\mathrm{MHz}, \mathrm{CDCl}_{3}$ ) of compound LA-2 gave peaks at $\delta 38.73$, 28.0, 79.03, 38.87, 55.32, 18.33, 34.30, 40.85, 50.46, 37.19, $20.95,25.17,38.08,42.85,27.45,35.60,43.01,48.33,48.0$, $150.98,29.87,40.01,29.7,15.36,16.12,15.99,14.56$, 18.02, 109.32 and $19.31 \mathrm{ppm}$. The ${ }^{13} \mathrm{C}$ NMR spectrum of compound LA-2 showed thirty signals indicating the presence of thirty carbons. The signals at $\delta 109.32$ and 150.98 were characteristic of olefinic carbons. A deshielded signal at $\delta 79.03$ indicated the presence of C-O group. All these ${ }^{1} \mathrm{H}$ NMR and ${ }^{13} \mathrm{C}$ NMR spectral data of LA-2 was in good agreement with the reported data ${ }^{\mathbf{1 6}}$ of lupeol and the compound LA-2 was establish as lupeol.

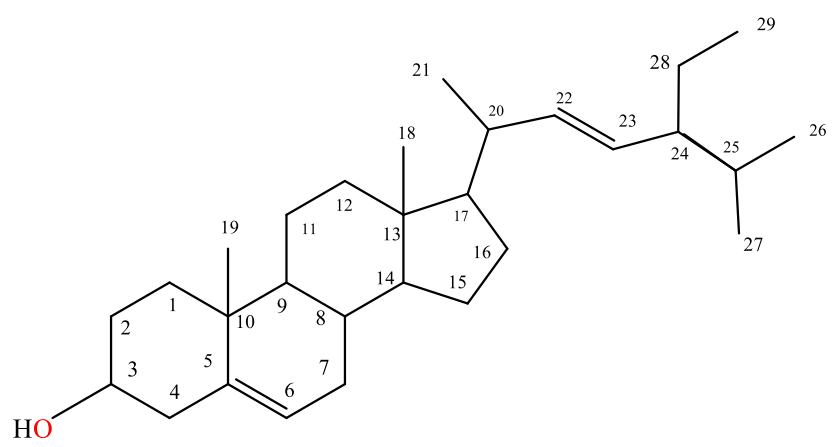

Fig. 1. Structure of LA-1 as stigmasterol

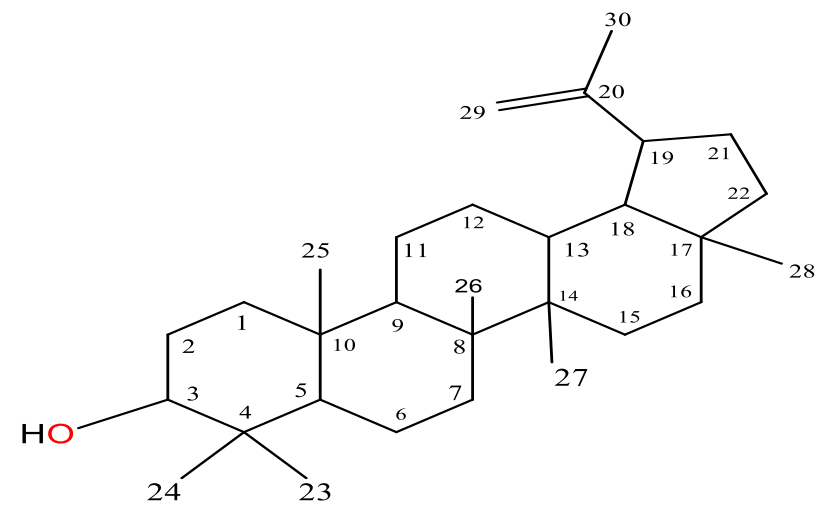

Fig. 2. Structure of LA-2 as lupeol

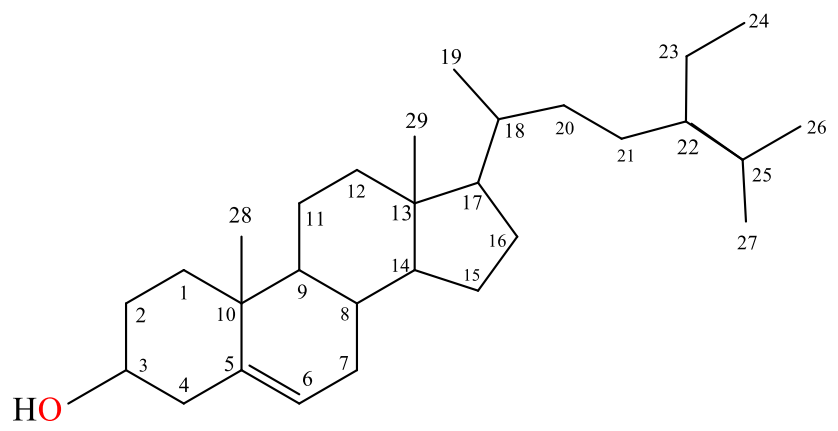

Fig. 3. Structure of LA-3 as $\beta$-sitosterol 


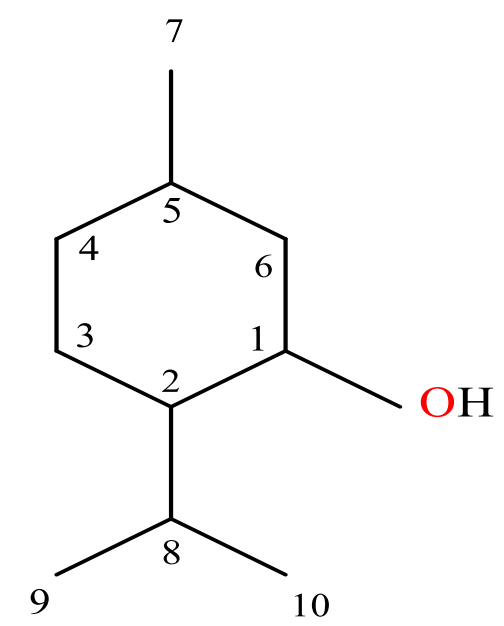

Fig. 4. Structure of LA-4 as menthol

\section{Characterization of compound LA-3}

The compound LA-3 ( $7.0 \mathrm{mg}$ ) was white crystalline solid, its melting point was found to be $148-150^{\circ} \mathrm{C}$ and having $\mathrm{R}_{\mathrm{f}}$ value 0.50 (in $98 \%$ DCM:2\% methanol). It was soluble in chloroform and dichloromethane. The IR spectrum of the compound LA-3 revealed absorption band at 3450, 2920, $2872,1650,1450,1365$ and $1040 \mathrm{~cm}^{-1}$. IR absorption band at $3419 \mathrm{~cm}^{-1}$ and at $1027 \mathrm{~cm}^{-1}$ were assignable to $\mathrm{O}-\mathrm{H}$ group and $\mathrm{C}-\mathrm{O}$ stretching, respectively. The absorption band at $1683 \mathrm{~cm}^{-1}$ due to $\mathrm{C}=\mathrm{C}$ bond stretching. ${ }^{1} \mathrm{H}$ NMR spectrum (400 MHz, $\mathrm{CDCl}_{3}$ ) of compound LA-3 showed peaks at $\delta 5.27,3.60,1.12,0.90,0.84,0.71$ and 1.07-2.08 ppm. The proton signals at $\delta 3.60$ and $5.27 \mathrm{ppm}$ were indicative of proton connected to the $\mathrm{C}-\mathrm{O}$ group and olefinic proton, respectively. The signals between $\delta 1.07-$ $2.08 \mathrm{ppm}$ were characteristic of steroidal nucleus. ${ }^{13} \mathrm{C}$ NMR spectrum $\left(100 \mathrm{MHz}, \mathrm{CDCl}_{3}\right)$ of compound LA-3 showed peaks at $\delta 38.76,31.82,79.05,41.13,143,122.68$, $32.68,32.43,46.49,37.08,24.73,39.29,41.68,55.24,27.2$, 28.11, 47.64, 33.82, 18.33, 33.06, 27.69, 45.9, 25.9, 15.55, 29.7, 23.57, 23.02, 17.05 and $15.33 \mathrm{ppm}$. The ${ }^{13} \mathrm{C}$ NMR spectrum of compound LA-3 showed the presence of twenty nine (29) carbons among them the signal at $\delta 79.05$ ppm was due to one oxymethine carbon and signals at $\delta$ 143.0 and $122.68 \mathrm{ppm}$ were due to two olefinic carbons. From the physical characteristics and spectral analysis $\left({ }^{1} \mathrm{H}\right.$ NMR and ${ }^{13} \mathrm{C}$ NMR) data of the compound LA-3 and comparing the reported value ${ }^{17}$ of ${ }^{1} \mathrm{H}$ NMR and ${ }^{13} \mathrm{C} N M R$ spectral data of $\beta$-sitosterol, the structure of the compound LA-3 was established as $\beta$-sitosterol.

\section{Characterization of compound LA-4}

The compound LA-4 ( $30 \mathrm{mg}$ ) was a waxy, crystalline substance, clear white in color, which was solid at room temperature and melts slightly above having $\mathrm{R}_{\mathrm{f}}$ value 0.6 (80\% DCM and 20\% n-hexane). It was soluble in chloroform and melting point was found to be $36-38^{\circ} \mathrm{C}$. The FT-IR spectrum of the compound LA-4 provided absorption band at 3266, 2959, 2872, 1448, 1383 and $1078 \mathrm{~cm}^{-1}$. ${ }^{1} \mathrm{H}$ NMR spectrum $\left(400 \mathrm{MHz}, \mathrm{CDCl}_{3}\right)$ of compound LA-4 showed peaks at $\delta 3.38,2.28,2.18,1.96$, $1.63,1.39,1.41,0.89,0.93,0.80$ and $1.16-0.97 \mathrm{ppm} .{ }^{13} \mathrm{C}$ NMR spectrum $\left(100 \mathrm{MHz}, \mathrm{CDCl}_{3}\right.$ ) of compound LA-4 showed peaks at $\delta 71.24,49.96,23.02,34.48,31.56$, $44.95,22.09,26.59,15.93$ and $20.91 \mathrm{ppm}$. IR absorption band at $3266 \mathrm{~cm}^{-1}$ assignable to $\mathrm{O}-\mathrm{H}$ group and bands at 2959 and $2872 \mathrm{~cm}^{-1}$ were due to the presence of aliphatic $\mathrm{C}-\mathrm{H}$ stretching. The absorption band at $1078 \mathrm{~cm}^{-1}$ was indicative of C-O stretching. The ${ }^{1} \mathrm{H}$ NMR signal at $\delta 3.38$ ppm having coupling constants $\mathrm{J}=4.0 \& 10.4 \mathrm{~Hz}$ indicated the presence of oxymethine proton. The broad singlet at $\delta 2.28 \mathrm{ppm}$ was the indicative of $-\mathrm{OH}$ group. The signals at $\delta 0.89,0.93$ and $2.18 \mathrm{ppm}$ indicated the presence of isopropyl group. The ${ }^{13} \mathrm{C}$ NMR spectrum of the isolated compound showed characteristic signals for three methyl carbons at $\delta 15.93$ (C-9), 20.19 (C-10) and $22.09 \mathrm{ppm}(\mathrm{C}-7)$, three methylene carbons at $\delta 23.02$ (C3), 34.48 (C-4) and $44.95 \mathrm{ppm}$ (C-6), three methine carbons at $\delta 26.59(\mathrm{C}-8), 31.56(\mathrm{C}-5)$ and $49.96 \mathrm{ppm}(\mathrm{C}-$ $2)$. The signal at $\delta 71.24 \mathrm{ppm}(\mathrm{C}-1)$ also indicative of one oxymethine carbon. Comparing the ${ }^{1} \mathrm{H}$ NMR and ${ }^{13} \mathrm{C}$ NMR data of the compound LA-4 with reported value ${ }^{18}$ of ${ }^{1} \mathrm{H}$ NMR and ${ }^{13} \mathrm{C}$ NMR of menthol, the structure of the compound was established as menthol.

\section{Antimicrobial activity screening}

Antimicrobial activity of $L$. aspera was estimated by using disc diffusion method ${ }^{\mathbf{1 3}}$. Crude methanolic extract of $L$. aspera and its different partitions i.e., n- hexane (HEX), chloroform $\left(\mathrm{CHCl}_{3}\right)$, dichloromethane (DCM), ethyl acetate (EA) and aqueous (AQ) were subjected to antimicrobial screening. In every case $400 \mu \mathrm{g}$ sample per disc was applied. Significant zone of inhibition against Gram positive $B$. subtilis $(11 \mathrm{~mm})$ and $S$. aureus $(8 \mathrm{~mm}), B$. megaterium $(12 \mathrm{~mm})$ and Gram negative $S$. paratyphi $(8$ $\mathrm{mm})$, S. typhi $(7 \mathrm{~mm})$, V. mimicus $(8 \mathrm{~mm})$, S. dysenteriae (9 $\mathrm{mm})$ and $V$. cholera $(8 \mathrm{~mm})$ was observed.

\section{Brine shrimp lethality bio assay}

Brine shrimp lethality bio assay experiment was also carried out by standard procedure ${ }^{\mathbf{1 4}}$. Freshly extracted different fractions of $L$. aspera were weighed and then a series of solutions of varying concentrations were prepared from the stock solutions by serial dilution method. The $\mathrm{LC}_{50}$ values of $\mathrm{MeOH}, \mathrm{HEX}, \mathrm{CHCl}_{3}, \mathrm{DCM}, \mathrm{EA}$ and AQ fractions were found to be 4.07, 9.36, 8.82, 14.35, 2.40 and $11.39 \mu \mathrm{g} / \mathrm{mL}$, respectively. Ethyl acetate (EA) and methanol (ME) fraction showed significant lethality whereas HEX and $\mathrm{CHCl}_{3}$ revealed moderate activity. Dichloromethane (DCM) and aqueous (AQ) showed very low activity.

\section{Cytotoxicity assay on cancer and non-cancer cell line}

Cytotoxicity test for the different extracts of L. aspera were tested against HeLa cell line (a human cervical carcinoma cell) and Vero cell line (a kidney epithelial cells extracted from an African green monkey) in Center for Advanced Research (CARS), University of Dhaka. $1 \mathrm{mg} / \mathrm{mL}$ sample 
of different extracts were applied on both HeLa and Vero cell but no significant cytotoxicity was observed on both HeLa and Vero cell at $1 \mathrm{mg} / \mathrm{mL}$ of sample inhibition.

\section{Total antioxidant capacity: Phosphomolybdenum method}

The total antioxidant capacity was estimated using phosphomolybdenum method and total antioxidant capacity of crude methanol fraction was found to be $59.40 \mathrm{mg} / \mathrm{g}$ of plant extract (expressed as ascorbic acid equivalents) which is the highest antioxidant capacity comparing with other fractions. On the other hand, hexane fraction was found to show $19.52 \mathrm{mg} / \mathrm{g}$ of plant extract (as ascorbic acid equivalents) which is the lowest antioxidant capacity comparing with other extracts.

\section{References}

1. Kundu, S., U. Salma, M. Sutradhar and N. Mandal, 2018. An update on the medicinal uses, phytochemistry and pharmacology of Leucas aspera, a medicinally important species. International Journal of Agriculture Innovations and Research, 6(4), 39-44.

2. Ghani, A, 2003. Medicinal plants of Bangladesh, Chemical constituents and uses. 2nd Edition, Asiatic society of Bangladesh, Dhaka, 1-16.

3. Raddy M. K., S. Viswanathan, P.T. Sambantham, S. Ramchandran and L. Kameswaran, 1986. Effect of Leucas aspera on experimental inflammation and mast cell degranulation. Ancient Science of Life, 5(3), 168-171.

4. Gupta, N., M. Agarwal, V. Bhatia, R.K. Sharma and E. Narang, 2011. A comparative anti-diabetic and hypoglycemic activity of the crude alcoholic extracts of the plant Leucas aspera and seeds of Pithecellobium bigemium in rats. International Journal of Research in Ayurveda and Pharmacy, 2(1), 275-280.

5. Chopra, R. N., S.I. Nayar and I.C. Chopra, 2002. Glossary of Indian medicinal plant. National Institute of Science Communication and Information Resources, New Delhi, 153.

6. Mangathayaru K., D. Thirumurugan, P.S. Patel, D.V. Pratap, D.J. David and J. Karthikeyan, 2006. Isolation and identification of nicotine from Leucas aspera (willd). Indian Journal of Pharm Science, 68(1), 88-90.

7. Khaleque A, M.E. Huq, M.S. Huq and M. H. Mansoor, 1970. Chemical investigations on Leucas aspera. I. Isolation of compound-A, 3-sitosterol and et-sitosterol from the aerial parts. Scientific Research, 7, 125-7.

8. Chatterjee S.K. and D.N. Majumdar, 1969. Chemical investigation of Leucas aspera. J. Inst. Chem, 41, 98-101.

9. Misra T.N., R.S. Singh, H.S. Pandey and S. Singh, 1995. A novel phenolic compound from Leucas aspera Spreng. Indian J Chem B, 34, 1108-10.

10. Misra T.N., R.S. Singh, C. Prasad and S. Singh, 1992. Two aliphatic ketols from Leucas aspera. Phytochemistry, 32, 199-201.

11. Kalachaveedu M., A. Ghosh, R. Ranjan and V.K. Venkat, 2006. Volatile constituents of Leucas aspera (Willd.), Journal of Essential Oil Research, 18(1), 104-5.

12. Edeoga H.O., D.E. Okwu and B.O. mbaebie, 2005. Phytochemical constituents of some Nigerian medicinal plants. African journal of biotechnology, 4(7), 685-688.

13. Bayer, C., L.V. Kalm and J.W. Fristrom, 1996. Gene regulation in imaginal disc and salivary gland development during Drosophila metamorphosis. In Metamorphosis: postembryonic reprogramming of gene expression in amphibian and insect cells, Academic Press, San Diego, CA, 321-361.

14. Meyer, B.N., N.R. Ferrigni, J.E. Putnam, L.B. Jacobsen, D.E. Nichols and J.L. McLaughlin, 1982. Brine Shrimp: A Convenient General Bioassay for Active Plant Constituents. Planta Medica, 45, 31-34.

15. Akhter, S., T. Muslim, M.A. Rahman and A. Quader, 2008. Sterols from Polygonum plebejum (Khudi bikatali). Dhaka univ. J. Sci., 56(2), 253-254.

16. Jain S., Pritam and S. Bari, 2010. Isolation of Lupeol, Stigmasterol and Campesterol from petroleum ether extract of woody stem of Wright tinctoria. Asian Journal of Plant Sciences, 9(3), 163-167.

17. Chaturvedula P. and I. Prakash, 2012. Isolation of Stigmasterol and $\beta$-Sitosterol from the dichloromethane extract of Rubus suavissimus .International Current Pharmaceutical Journal, 1(9), 239-242.

18. Ahmed, A., K.K. Aggarwal, S.K. Srivastava, J. Ahmad and S. Kumar, 2011. Carbon-13 and Proton NMR Shift Assignments and Physical constants of some L-Menthol Derivatives, Journal of Essential Oil Research, 12(6), 775780. 